\title{
Mulberry extract as an ecofriendly anticoccidial agent: in vitro and in vivo application
}

\author{
Extrato de amoreira como agente anticoccidiano ecologicamente correto: \\ aplicação in vitro e in vivo
}

\author{
Felwa Abdullah Thagfan ${ }^{\text {* }}$ (1D; Wafa Abdullah Al-Megrin'; Saleh Al-Quraishy²; Mohamed Abdel Monem Dkhil2,3 \\ ${ }^{1}$ Department of Biology, College of Science, Princess Nourah Bint Abdulrahman University, Riyadh, Saudi Arabia \\ ${ }^{2}$ Department of Zoology, College of Science, King Saud University, Riyadh, Saudi Arabia \\ ${ }^{3}$ Department of Zoology and Entomology, Faculty of Science, Helwan University, Cairo, Egypt
}

How to cite: Thagfan FA, Al-Megrin WA, Al-Quraishy S, Dkhil MAM. Mulberry extract as an ecofriendly anticoccidial agent: in vitro and in vivo application. Braz J Vet Parasito/ 2020; 29(4): e009820. https://doi.org/10.1590/S1984-29612020072

\begin{abstract}
Natural products are ecofriendly agents that can be used against parasitic diseases. Eimeria species cause eimeriosis in many birds and mammals and resistance to available medications used in the treatment of eimeriosis is emerging. We investigated the in vitro and in vivo activity of Morus nigra leaf extracts (MNLE) against sporulation of oocysts and infection of mice with Eimeria papillata. Phytochemical analysis of MNLE showed the presence of seven compounds and the in vitro effects of MNLE, amprolium, DettolTM, formalin, ethanol, and phenol were studied after incubation with oocysts before sporulation. Furthermore, infection of mice with E. papillata induced an oocyst output of approximately $12 \times 10^{5}$ oocysts/g of feces. MNLE significantly decreased oocyst output to approximately $86 \%$ and the total number of parasitic stages in the jejunum by approximately $87 \%$. In addition, the reduction in the number of goblet cells in the jejuna of mice was increased after treatment. These findings suggest that mulberry exhibited powerful anticoccidial activity.
\end{abstract}

Keywords: Morus nigra extract, sporulation, eimeriosis, oocysts, mice, jejunum.

\section{Resumo}

Os produtos naturais são agentes ecologicamente corretos que podem ser usados contra doenças parasitárias. As espécies de Eimeria causam eimeriose em muitas aves e mamíferos e a resistência aos medicamentos disponíveis usados no tratamento da eimeriose está emergindo. Foram investigadas as atividades in vitro e in vivo dos extratos de folhas de Morus nigra (MNLE) contra esporulação de oocistos e infecção de camundongos com Eimeria papillata. A análise fitoquímica do MNLE mostrou a presença de sete compostos e os efeitos in vitro do MNLE, amprolium, DettolTM, formalina, etanol e fenol foram estudados após incubação com oocistos antes da esporulação. Além disso, a infecção de camundongos com E. papillata induziu uma produção de oocistos de aproximadamente $12 \times 105$ oocistos / $g$ de fezes. O MNLE reduziu significativamente a produção de oocistos para aproximadamente $86 \%$, e o número total de estágios parasitários no jejuno em aproximadamente $87 \%$. Além disso, a redução no número de células caliciformes no jejuno de camundongos aumentou após o tratamento. Esses achados sugerem que a amoreira exibia uma poderosa atividade anticoccidiana.

Palavras-chave: Extrato de Morus nigra, esporulação, eimeriose, oocistos, camundongos, jejuno. 


\section{Introduction}

Coccidiosis, one of the most serious diseases affecting many animals (Mehlhorn, 2014), is caused by infection with Eimeria spp. (Andrews et al., 2004) and leads to gastrointestinal problems characterized by diarrhea, poor growth performance, and in some cases death (Collier et al., 2008; Orengo et al., 2012). Furthermore, infections induced by Eimeria spp. can foster opportunistic infections with other pathogens such as bacteria (Collier et al., 2008). Consequently, this pathogen causes massive economic losses worldwide (Shirley et al., 2007; Chapman, 2014).

Eimeria oocysts are relatively resistant to environment conditions, which makes control measures difficult (Stephen et al., 1997). Therefore, disruption of the sporulation process is a critical point where this parasite can be controlled (Mai et al., 2009). In addition, the prevalent prophylactic use of anticoccidial feed additives has led to widespread resistance (Stephen et al., 1997), which has currently been reported against available drugs (Williams, 1999; Chapman, 2014).

Medicinal plants are the major resources of all alternative or indigenous systems of medicine and are considered promising sources for discovery of new chemical compounds (Kalia, 2009). In addition to targeting parasites, these products also have organ-protecting properties in hosts infected with Eimeria (Wunderlich et al., 2014). Morus nigra (black mulberry) is a perennial woody plant (Pan \& Lou, 2008) that belongs to the family Moraceae (Yang et al., 2010). The genus Morus is found in warm and temperate regions and subtropical regions of Asia, Africa, North America (Pérez-Gregorio et al., 2011) including the US (Abbasi et al., 2014), and South Europe. The fruits, bark, and leaves of black mulberry are used medicinally as analgesic, antipyretic and anti-diabetic (Rodrigues et al., 2019) and, in particular, the fruits are used against dysentery (Ercisli \& Orhan, 2007).

Additionally, the antiparasitic activity of Morus alba (Riffat et al., 1986; Nguyen-Pouplin et al., 2007) and anthelmintic activity of Morus indica (Mughal et al., 2013) were reported. The present study was conducted to investigate the in vitro and in vivo effects of $M$. nigra leaf extracts on Eimeria papillata oocysts sporulation and viability.

\section{Materials and Methods}

\section{Extract preparation of extract}

The M. nigra leaf extract (MNLE) was prepared using leaves obtained from Riyadh, Saudi Arabia and the botanical identity of the plant was confirmed by a taxonomist at the Department of Botany, University of King Saud. The leaves (100 g) were air-dried at $40{ }^{\circ} \mathrm{C}$, ground into a powder, and then extracted with methanol (70\%) for $24 \mathrm{~h}$ at $4{ }^{\circ} \mathrm{C}$. The obtained extract was concentrated and dried in a rotary vacuum evaporator (Yamato RE300, Japan) as previously reported by Dkhil et al. (2013). Distilled water was used to dissolve the powder for the various experiments.

\section{Phytochemical analysis}

The phytochemical analysis of MNLE was performed according to the recommended protocol of Kanthal et al. (2014). The gas chromatography-mass spectrometry (GC-MS) analysis was performed using a Thermo Scientific, Trace GC Ultra and ISQ single quadruple MS (Miami, CA, USA).

\section{Oocyst sporulation}

Fresh E. papillata unsporulated oocysts were originally obtained from Prof. Mehlhorn at Duesseldorf University (Duesseldorf, Germany) and the parasite was maintained by passaging in mice (Dkhil et al., 2011). The unsporulated oocysts $\left(1 \times 10^{5}\right)$ were incubated in $5 \mathrm{~mL}$ potassium dichromate containing one of the following: MNLE (100, 200, and $300 \mathrm{mg} / \mathrm{mL}$ ), $8.3 \mathrm{mg}$ amprolium (Veterinary Agriculture Products Company [VAPCO], Jordan), $109 \mu \mathrm{L} \mathrm{Dettol}{ }^{\mathrm{TM}}$, or $25 \mu \mathrm{L}$ phenol while $5 \mathrm{~mL}$ potassium dichromate (2.5\%) alone was used as the control. In addition, unsporulated oocysts $\left(1 \times 10^{5}\right)$ were incubated in $5 \mathrm{~mL}$ distilled water, ethanol $(70 \%)$, and formalin (5\%). We used three replicates for each treatment and all Petri dishes used incubated for 48 and $90 \mathrm{~h}$ at $25-29^{\circ} \mathrm{C}$ (Gadelhaq et al., 2018). The sporulated oocysts were counted using a Mcmaster chamber and the percentage sporulation was calculated using the following equation:

Sporulation $(\%)=($ Number of sporulated oocysts / total number of oocysts $) \times 100$ 


\section{Infection of animals}

Adult male C57BL/6 mice (9-11 weeks old) were used. The experiments were approved by the institutional review board of the Princess Nourah Bint Abdulrahman University (IRB Approval Number: 19-0259). Fresh faecal pellets were collected and weighed for each mouse once every $24 \mathrm{~h}$ and the bedding was changed to eliminate reinfection. The output of oocysts was calculated as mentioned previously by Schito et al. (1996).

For oocyst flotation, the fecal pellets from each individual mouse were suspended and diluted using $2.5 \%(\mathrm{w} / \mathrm{v})$ potassium dichromate in saturated sodium chloride $(\mathrm{NaCl})$. Each mouse was inoculated orally with $100 \mu \mathrm{L}$ sterile saline solution containing $10^{3} \mathrm{E}$. papillata sporulated oocysts. A McMaster chamber was used to count the oocysts, and the results are expressed as the number per gram of wet feces (Dkhil et al., 2011).

\section{Experimental design}

The mice were divided into six groups of eight animals each group. The first group (control) was daily gavaged with $100 \mu \mathrm{L} 0.9 \% \mathrm{NaCl}$ for 5 days. The second group was daily treated with $100 \mu \mathrm{L}$ MNLE ( $200 \mathrm{mg} / \mathrm{kg}$ ) by oral gavage, while the third, fourth, fifth, and sixth group were orally infected with $10^{3} \mathrm{E}$. papillata oocysts. The last three groups were daily treated for 5 days with 200, 400, and 800 mg/kg of MNLE, respectively.

\section{Sample collection}

Fresh feces samples were collected from the mice on day 5 after infection, where each mouse was separated in this day in a small cage to collect its faeces and the oocysts shed per gram of feces was calculated (Schito et al., 1996). Then, all the mice were euthanized and parts of the jejunum were collected and fixed in formalin (10\%) for the histological and histochemical examination.

\section{Number of oocysts in jejunum}

Pieces of the jejunum were fixed in 10\% neutral formalin buffered, dehydrated in ethanol, embedded in paraffin wax, and then cut into 5- $\mu \mathrm{m}$ thick sections. The sections were stained with hematoxylin and eosin (H\&E) (Drury \& Wallington, 1980). Oocysts were counted in 10 well-oriented villous-crypt units (VCU) for each animal using Olympus BX61 light microscope (Tokyo, Japan).

\section{Number of goblet cells}

The number of goblet cells was determined in Alcian blue-stained sections. The number was expressed as mean goblet cells per 10 VCU (Allen et al., 1986).

\section{Statistical analysis}

Analysis of ANOVA was carried out in one way, and statistical comparisons between groups were made using the Duncan method. Values have been expressed as mean \pm SD, at a significance level of $\leq 0.05$. SigmaPlot software (version 11) was used for statistical analysis.

\section{Results}

Figure 1 shows the GC-MS chromatogram of MNLE. The phytochemical components identified were 1,3-benzenediamine, 2,4-dinitro-N3, N3-dipropyl-6-(trifluoromethyl)-, ß-carotene, gamabufotalin, ricinoleic acid, cholesteryl benzoate, tetradecanoic acid, and methotrexate (Table 1). After a $48 \mathrm{~h}$ incubation with MNLE (200 and $300 \mathrm{mg} / \mathrm{mL}$ ), formalin, or ethanol, the E. papillata unsporulated oocysts showed no sporulation. However, oocysts incubated with potassium dichromate $(2.5 \%)$, MNLE $(100 \mathrm{mg} / \mathrm{mL})$, amprolium, and Dettol ${ }^{\mathrm{TM}}$ showed different levels of sporulation (Table 2).

Incubation with MNLE (300 mg/mL), formalin, and ethanol for $90 \mathrm{~h}$ inhibited sporulation by approximately $100 \%$ (Table 2). MNLE (100 and $200 \mathrm{mg} / \mathrm{mL}$ ), amprolium, Dettol ${ }^{\mathrm{TM}}$, and phenol induced average sporulation levels of $90.4 \%, 31 \%, 81.1 \%, 87 \%$ and $28 \%$, respectively. On day 5 post-infection, the highest oocyst output was level was $12.1 \pm 6.2 \times 10^{5}$ oocysts $/ g$ of feces in infected mice. Treatment with different doses of MNLE (200,400, and $\left.800 \mathrm{mg} / \mathrm{kg}\right)$ significantly $(P<0.01)$ reduced the oocyst output to $86.8 \%, 86 \%$, and $93.8 \%$, respectively (Figure 2$)$. For further 


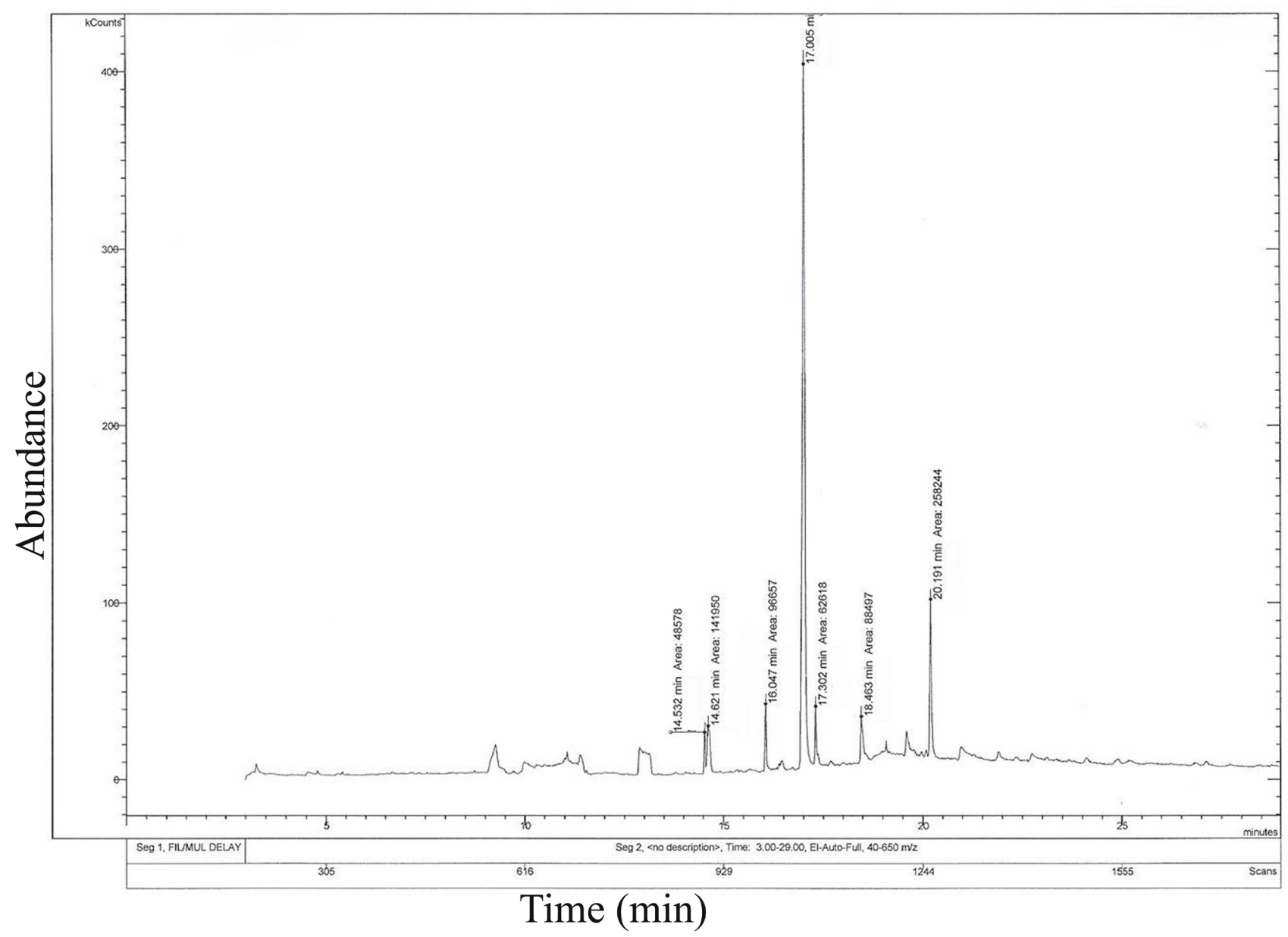

Figure 1. GC-MS Chromatogram of methanolic leaf extract of Morus nigra.

Table 1. Identification of phytochemical compounds by GC-Mass in Morus nigra leaf extracts. RT: Retention time, M-H: Protonated molecuole, MS: Mass acquired range.

\begin{tabular}{|c|c|c|c|c|c|}
\hline RT & Assignment & $\begin{array}{l}\text { Molecular } \\
\text { formula }\end{array}$ & $\begin{array}{l}{[\mathrm{M}-\mathrm{H}]^{-}} \\
(\mathrm{m} / \mathrm{z})\end{array}$ & $\begin{array}{l}\text { MS } \\
(\mathrm{m} / \mathrm{z})\end{array}$ & $\begin{array}{c}\text { Peak area } \\
(\%)\end{array}$ \\
\hline 14.5 & 1,3-Benzenediamine, 2,4-dinitro-N3, N3-dipropyl-6-(trifluoromethyl)- & $\mathrm{C}_{13} \mathrm{H}_{17} \mathrm{~F}_{3} \mathrm{~N}_{4} \mathrm{O}_{4}$ & 349 & $18-321$ & 2.87 \\
\hline 14.6 & ß-Carotene & $\mathrm{C}_{40} \mathrm{H}_{56}$ & 535 & 43-536 & 8.4 \\
\hline 16.1 & Gamabufotalin & $\mathrm{C}_{24} \mathrm{H}_{34} \mathrm{O}_{5}$ & 401 & 43-366 & 5.7 \\
\hline 17.0 & Ricinoleic acid & $\mathrm{C}_{18} \mathrm{H}_{34} \mathrm{O}_{3}$ & 297 & $55-166$ & 58.8 \\
\hline 17.3 & Cholesteryl benzoate & $\mathrm{C}_{34} \mathrm{H}_{50} \mathrm{O}_{2}$ & 489 & 43-368 & 3.7 \\
\hline 18.5 & Tetradecanoic acid & $\mathrm{C}_{28} \mathrm{H}_{56} \mathrm{O}_{2}$ & 423 & $41-229$ & 5.23 \\
\hline 20.2 & Methotrexate & $\mathrm{C}_{20} \mathrm{H}_{22} \mathrm{~N}_{8} \mathrm{O}_{5}$ & 453 & $41-176$ & 15.3 \\
\hline
\end{tabular}

investigations, we have chosen the dose $200 \mathrm{mg} / \mathrm{kg}$ as a lower dose that can help to avoid adverse side effects, drug diversion, and toxicity where there was no significant difference in effect between the other treated groups.

MNLE $(200 \mathrm{mg} / \mathrm{kg})$ significantly $(P<0.01)$ decrease the oocyst number in the mouse jejuna by approximately $86 \%$ (Figure 3). Finally, examination of Alcian blue-stained sections showed that the infection significantly reduced the number of goblet cells in the jejunum villi (Figure 4). Compared to the infected group, mice treated with $200 \mathrm{mg} / \mathrm{kg}$ MNLE showed a significant $(P<0.01)$ increase in the number of goblet cells by approximately $71 \%$ (Figure 5). 
Table 2. Effect of Morus nigra on sporulation of E. papillata oocysts. MNLE: Morus nigra leaf extracts, P: Probability.

\begin{tabular}{|c|c|c|c|c|}
\hline Groups & Time & Unsporulated oocysts (\%) & Inhibition of sporulation (\%) & $P$ value \\
\hline \multirow{2}{*}{$\begin{array}{l}\text { Potassium dichromate } \\
\qquad(2.5 \%)\end{array}$} & $48 \mathrm{~h}$ & $83.03 \pm 2.9$ & 0 & - \\
\hline & $90 \mathrm{~h}$ & $5.5 \pm 1$ & 0 & - \\
\hline \multirow{2}{*}{$\begin{array}{c}\text { MNLE } \\
(100 \mathrm{mg} / \mathrm{ml})\end{array}$} & $48 \mathrm{~h}$ & $95 \pm 1$ & $70.5 \pm 1$ & 0.01 \\
\hline & $90 \mathrm{~h}$ & $9.6 \pm 1$ & $3.3 \pm 1$ & 0.01 \\
\hline \multirow{2}{*}{$\begin{array}{c}\text { MNLE } \\
(200 \mathrm{mg} / \mathrm{mL})\end{array}$} & $48 \mathrm{~h}$ & $100 \pm 0.1$ & $100 \pm 0.2$ & 0.01 \\
\hline & $90 \mathrm{~h}$ & $69 \pm 1$ & $67.2 \pm 1$ & 0.01 \\
\hline \multirow{2}{*}{$\begin{array}{c}\text { MNLE } \\
(300 \mathrm{mg} / \mathrm{mL})\end{array}$} & $48 \mathrm{~h}$ & $100 \pm 0.2$ & $100 \pm 0.2$ & 0.01 \\
\hline & $90 \mathrm{~h}$ & $100 \pm 0.2$ & $100 \pm 0.2$ & 0.01 \\
\hline \multirow[t]{2}{*}{ Amprolium } & $48 \mathrm{~h}$ & $88.1 \pm 1$ & $29.7 \pm 1$ & 0.01 \\
\hline & $90 \mathrm{~h}$ & $18.9 \pm 1$ & $14.1 \pm 1$ & 0.01 \\
\hline \multirow[t]{2}{*}{ Formalin } & $48 \mathrm{~h}$ & $100 \pm 0.2$ & $100 \pm 0.2$ & 0.01 \\
\hline & $90 \mathrm{~h}$ & $100 \pm 0.1$ & $100 \pm 0.2$ & 0.01 \\
\hline \multirow[t]{2}{*}{ Dettol ${ }^{\mathrm{TM}}$} & $48 \mathrm{~h}$ & $99 \pm 0.9$ & $94.1 \pm 0.9$ & 0.01 \\
\hline & $90 \mathrm{~h}$ & $13 \pm 1$ & $7.9 \pm 1$ & 0.01 \\
\hline \multirow[t]{2}{*}{ Ethanol } & $48 \mathrm{~h}$ & $100 \pm 0.2$ & $100 \pm 0.2$ & 0.01 \\
\hline & $90 \mathrm{~h}$ & $100 \pm 0.2$ & $100 \pm 0.2$ & 0.01 \\
\hline \multirow[t]{2}{*}{ Phenol } & $48 \mathrm{~h}$ & $100 \pm 0.2$ & $100 \pm 0.2$ & 0.01 \\
\hline & $90 \mathrm{~h}$ & $72 \pm 1$ & $70 . \pm 1$ & 0.01 \\
\hline
\end{tabular}

Values were expressed as mean \pm SD.

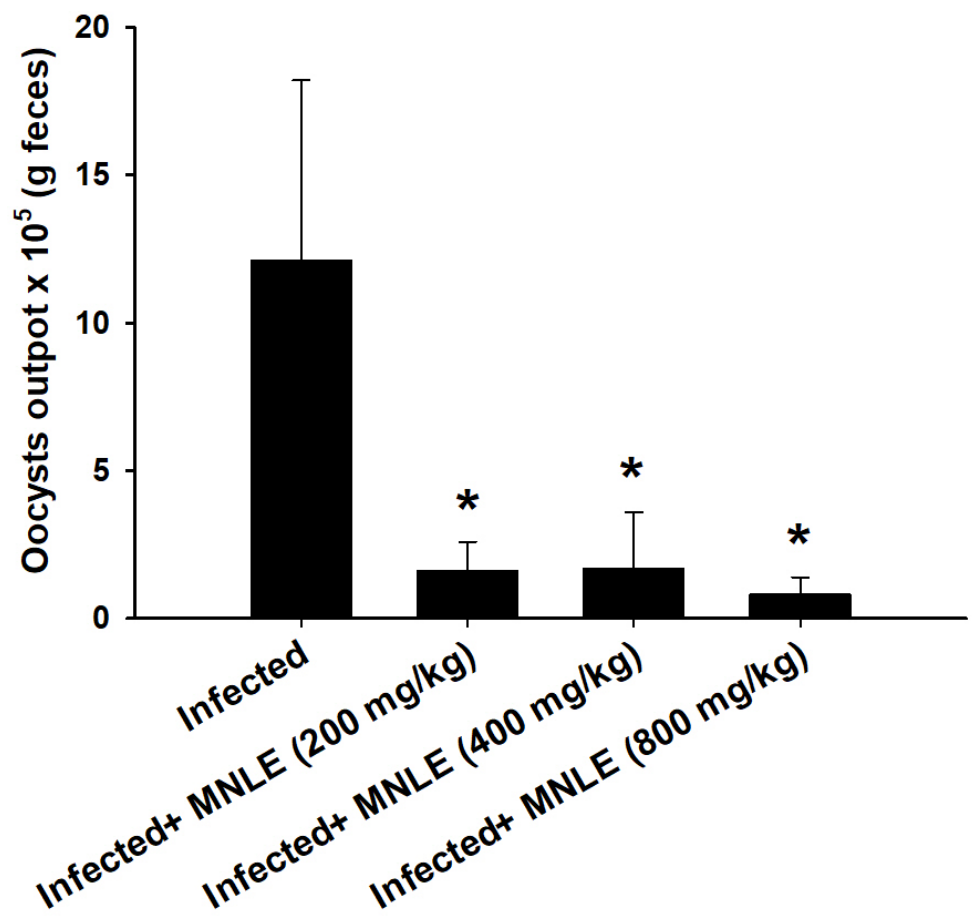

Figure 2. Effect of M. nigra extract on oocyst output on day 5 postinfection with E. papillata oocysts. *Significance against the infected group $(P<0.01)$. 


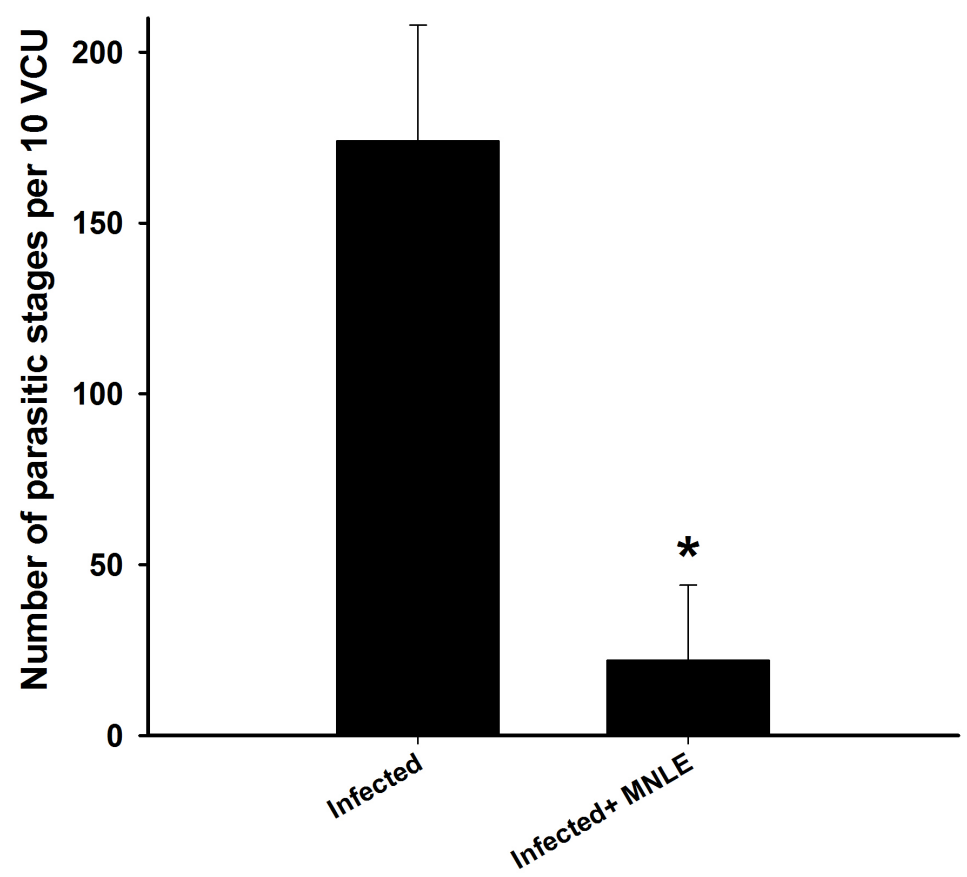

Figure 3. Effect of M. nigra extract on the number of parasitic stages in ten well-orientated villous-crypt units (VCU) for each mouse, on the fifth day of infection with E. papillata. *Significant at $\mathrm{p}<0.01$. MNLE: Morus nigra leaf extracts.
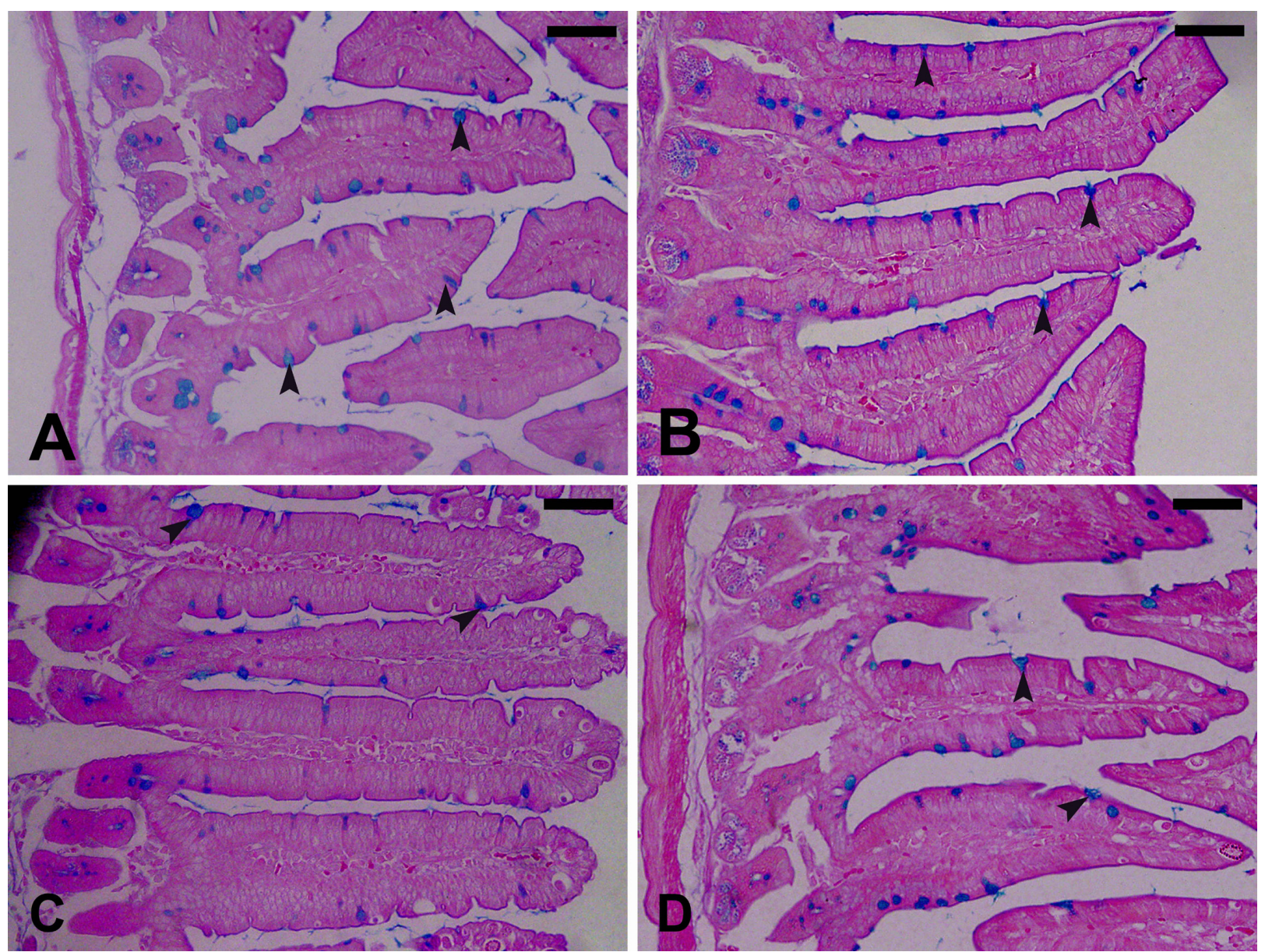

Figure 4. Effect of $M$. nigra extract on mice jejunal goblet cells (arrow head) infected with E. papillata. (A) non-infected control group (B) MNLE treated group (C) E. papillata infected group with decreased number of goblet cells (D) infected-MNLE treated group. Sections were stained with Alcian blue. Bar $=50 \mu \mathrm{m}$. MNLE: Morus nigra leaf extracts. 


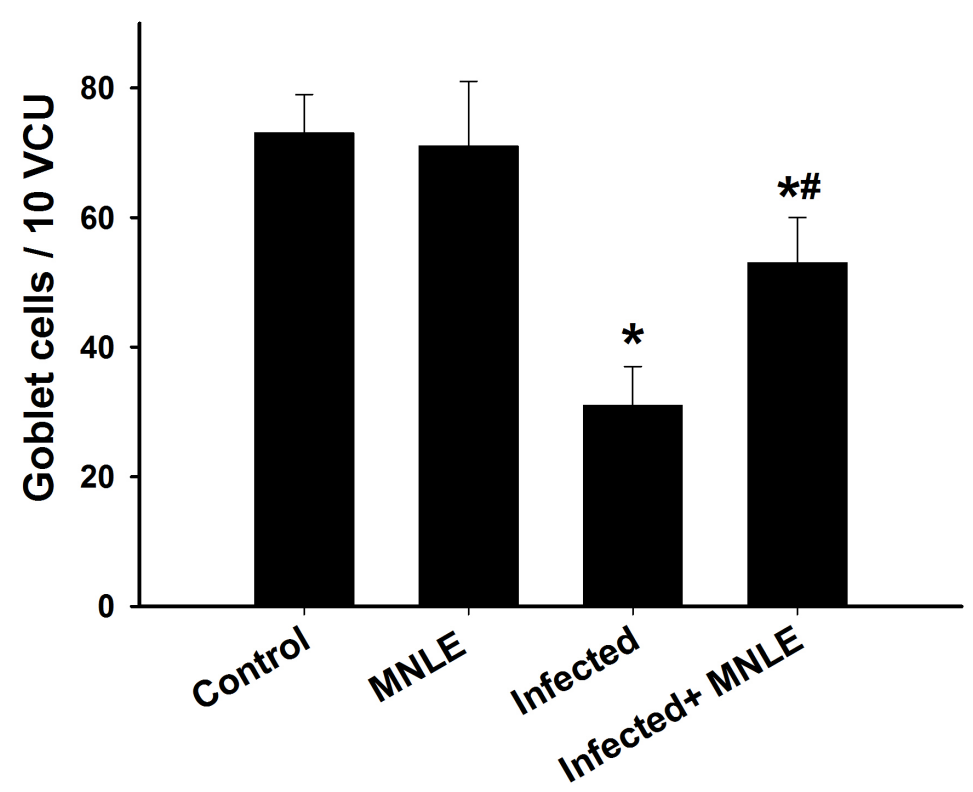

Figure 5. Effect of M. nigra extract on the number of goblet cells on day 5 p.i. with E. papillata. *Significance against non-infected control group $(p \leq 0.01)$. \#Significance against E. papillata-infected group $(p<0.01)$. MNLE: Morus nigra leaf extracts.

\section{Discussion}

Eimeriosis affects most animal species, causing considerable economic loss in many countries (Andrews et al., 2004). E. papillata infections occur when sporozoites of ingested sporulated oocysts are released, invade the jejunal epithelial cells, and rapidly multiply before oocysts are formed. Within the oocysts, outside the host sporogony occurs and they become infectious (Pakandl, 2005). Drug resistant eimeriosis has been reported (Williams, 1999; Chapman, 2014) and, therefore, research into the use natural of products as antiparasitic agents has been the focus of attention because these products are more effective, less harmful, and exhibit fewer less side effects than conventional chemical agents (Wunderlich et al., 2014).

Several studies have reported the effects of mulberry in treating many diseases (Ody, 2000; Naderi et al., 2004; Wang et al., 2009) and its potential effectiveness as an antiparasitic agent (Riffat et al., 1986; Ercisli \& Orhan 2007; Nguyen-Pouplin et al., 2007). In this study, MNLE (300 mg/mL) affected the oocysts sporulation, which is attributable to the presence of numerous bioactive phytochemical constituents (Sharma et al., 2010). In addition, our data showed that formalin (5\%) as a hazard chemical completely inhibited sporulation of E. papillata and Gadelhaq et al. (2018) reported that formalin (10\%) completely inhibited sporulation of Eimeria tenella. In addition, Chroustová \& Pinka (1987) reported that formalin (2\%) significantly affected sporulation of E. tenella oocyst. Formalin contains a highly reactive chemical (40\% formaldehyde in water) (Power, 1995) that interacts with proteins in vitro (Fraenkel-Conrat et al., 1945) to inhibit sporulation.

Ethanol (70\%) inhibited sporulation and oocyst wall deterioration, considering that the most potent concentration of antimicrobial alcohol is between 60 to 90\% (McDonnell \& Russell, 1999). Ethanol causes rapid denaturation of proteins, disrupts membranes, and causes subsequent interference with metabolism and cell lysis (Morton, 1983; Larson \& Morton, 1991). In addition, phenol (10\%) has been reported to inhibit sporulation (Samaha et al., 2013) whereas, in contrast, Detto ${ }^{\mathrm{TM}}$ had no effect on oocyst sporulation. These findings may be because the oocyst wall is impermeable to water-soluble substances and resistant to proteolysis (Kuticic \& Wikerhauser, 1996; Mai et al., 2009).

Jejunal infection with E. papillata in mice results in oxidative damage and serious local and systemic inflammatory responses (Dkhil et al., 2013). M. nigra is a plant that possesses anti-inflammatory (Yildirim et al., 2019), antioxidant (Lee et al., 2018), and antiparasitic (Ercisli \& Orhan, 2007) activity. The leaves of black mulberry contain flavonoids, ascorbic, and phenolics (Iqbal et al., 2012; Chen et al., 2016). MNLE showed anticoccidial activity following treatment of mice, as evidenced by a significant reduction in the production of $E$. papillata oocysts in infected mouse feces and oocysts in the jejunal villi. These results are in agreement with those of other studies that investigated the Punica granatum plant (Amer et al., 2015) and Azadirachta indica (Dkhil et al., 2013) as potential sources of anticoccidial agents. 
Parasitic infections cause a decrease in the number of goblet cells, which are known to be significant immunocompetent intestinal cells that secrete mucus (Linh et al., 2009). These cells may be reduced by the parasite-induced damage to stem cells (Cheng, 1974). A decrease in the number of goblet cells encourages an increase in opportunistic pathogens or their penetration of the local epithelium (Yunus et al., 2005). MNLE significantly increased the number of goblet cells, which was likely mediated by the numerous bioactive phytochemical constituents present in mulberry leaves (Sharma et al., 2010).

Different plant or herbal extracts are widely used as poultry diets to promote growth rates and animal health, particularly when health challenges are required. Quite enough research has confirmed the beneficial effects of plant extract on poultry productivity (Alçiçek et al., 2004; Gracia et al., 2016). Due to the anticoccidial activity of MNLE, we assumed that it could be used as a food additive in poultry feed.

Our results indicate that MNLE possessed a powerful antiparasitic and anti-sporulation activity. Additional studies are needed to elucidate the histological and molecular mechanism of sporulation inhibition by MNLE and its protective effects against $E$. Papillata-induced intestinal injury.

\section{Acknowledgements}

This research was funded by the Deanship of Scientific Research at Princess Nourah bint Abdulrahman University, through the young researcher funding program (Grant no\# YR-1440-7).

\section{References}

Abbasi AM, Khan MA, Ahmad M, Munir M, Zafar M, Sultana S, et al. Ethnobotanical and taxonomic screening of genus Morus for wild edible fruits used by the inhabitants of Lesser Himalayas-Pakistan. J Med Plants Res 2014; 8(25): 889-898. http://dx.doi. org/10.5897/JMPR2010.733.

Alçiçek A, Bozkurt M, Çabuk M. The effect of a mixture of herbal essential oils, an organic acid or a probiotic on broiler performance. S Afr J Anim Sci 2004; 34(4): 217-222.

Allen A, Hutton DA, Leonard AJ, Pearson JP, Sellers LA. The role of mucus in the protection of the gastroduodenal mucosa. Scand J Gastroenterol Supp/ 1986;21(Suppl 125): 71-78. http://dx.doi.org/10.3109/00365528609093820. PMid:3103205.

Amer OS, Dkhil MA, Hikal WM, Al-Quraishy S. Antioxidant and anti-inflammatory activities of pomegranate (Punica granatum) on Eimeria papillata-induced infection in mice. BioMed Res Int 2015; 2015: 219670. http://dx.doi.org/10.1155/2015/219670. PMid:25654088.

Andrews AH, Blowey RW, Boyd H, Eddy RG. Bovine medicine disease and husbandry of cattle. 2nd ed. Oxford: Blackwell Science; 2004.

Chapman HD. Milestones in avian coccidiosis research: a review. Poult Sci 2014; 93(3): 501-511. http://dx.doi.org/10.3382/ ps.2013-03634. PMid:24604841.

Chen H, Pu J, Liu D, Yu W, Shao Y, Yang G, et al. Anti-inflammatory and antinociceptive properties of flavonoids from the fruits of black mulberry (Morus nigra L.). PLoS One 2016; 11(4): e0153080. http://dx.doi.org/10.1371/journal.pone.0153080. PMid:27046026.

Cheng $\mathrm{H}$. Origin, differentiation and renewal of the four main epithelial cell types in the mouse small intestine. II Mucous cells. Am J Anat 1974; 141(4): 481-501. http://dx.doi.org/10.1002/aja.1001410404. PMid:4440633.

Chroustová E, Pinka K. The efficiency of disinfectants on the oocysts of Eimeria tenella. Acta Vet Brno 1987; 56(1-2): 141-149. http:// dx.doi.org/10.2754/avb198756010141.

Collier CT, Hofacre CL, Payne AM, Anderson DB, Kaiser P, Mackie RI, et al. Coccidia-induced mucogenesis promotes the onset of necrotic enteritis by supporting Clostridium perfringens growth. Vet Immunol Immunopathol 2008; 122(1-2): 104-115. http:// dx.doi.org/10.1016/j.vetimm.2007.10.014. PMid:18068809.

Dkhil MA, Abdel-Baki AS, Wunderlich F, Sies H, Al-Quraishy S. Anticoccidial and antiinflammatory activity of garlic in murine Eimeria papillata infections. Vet Parasito/ 2011; 175(1-2): 66-72. http://dx.doi.org/10.1016/j.vetpar.2010.09.009. PMid:20943319.

Dkhil MA, Al-Quraishy S, Abdel Moneim AE, Delic D. Protective effect of Azadirachta indica extract against Eimeria papillata-induced coccidiosis. Parasitol Res 2013; 112(1): 101-106. http://dx.doi.org/10.1007/s00436-012-3109-1. PMid:22972359.

Drury RAB, Wallington EA. Carleton's histological technique. 5th ed. Oxford: Oxford University Press; 1980.

Ercisli S, Orhan E. Chemical composition of white (Morus alba), red (Morus rubra) and black (Morus nigra) mulberry fruits. Food Chem 2007; 103(4): 1380-1384. http://dx.doi.org/10.1016/j.foodchem.2006.10.054. 
Fraenkel-Conrat H, Cooper M, Olcott HS. The reaction of formaldehyde with proteins. J Am Chem Soc 1945; 67(6): 950-954. http:// dx.doi.org/10.1021/ja01222a023.

Gadelhaq SM, Arafa WM, Abolhadid SM. In vitro activity of natural and chemical products on sporulation of Eimeria species oocysts of chickens. Vet Parasitol 2018; 251: 12-16. http://dx.doi.org/10.1016/j.vetpar.2017.12.020. PMid:29426468.

Gracia MI, Millán C, Sánchez J, Guyard-Nicodème M, Mayot J, Carre Y, et al. Efficacy of feed additives against Campylobacter in live broilers during the entire rearing period: part B. Poult Sci 2016; 95(4): 886-892. http://dx.doi.org/10.3382/ps/pev346. PMid:26706354.

Iqbal S, Younas U, Sirajuddin U, Chan KW, Sarfraz RA, Uddin K. Proximate composition and antioxidant potential of leaves from three varieties of Mulberry (Morus sp.): a comparative study. Int J Mol Sci 2012; 13(6): 6651-6664. http://dx.doi.org/10.3390/ ijms13066651. PMid:22837655.

Kalia AN. Textbook of industrial pharmacognosy. 1st ed. New Delhi: CBS Publishers and Distributers; 2009.

Kanthal LK, Dey A, Satyavathi K, Bhojaraju P. GC-MS analysis of bio-active compounds in methanolic extract of Lactuca runcinata DC. Pharmacognosy Res 2014; 6(1): 58-61. http://dx.doi.org/10.4103/0974-8490.122919. PMid:24497744.

Kuticic V, Wikerhauser T. Studies of the effect of various treatments on the viability of Toxoplasma gondii tissue cysts and Oocysts. In: Gross U, editor. Toxoplasma gondii: current topics in microbiology and immunology. Berlin: Springer; 1996. (vol. 219). http:// dx.doi.org/10.1007/978-3-642-51014-4_23.

Larson EL, Morton HE. Alcohols. In: Bloch SS, editor. Disinfection, sterilization, and preservation. 4th ed. Philadelphia: Lea \& Febiger; 1991. p. 191-203.

Lee J, Lee HJ, Lee J. Coating rice with mulberry leaves rich in deoxynojirimycin ameliorates hyperglycemia and dyslipidemia in C57BL/KsJ db/db mice. Nutr Res Pract 2018; 12(6): 469-478. http://dx.doi.org/10.4162/nrp.2018.12.6.469. PMid:30515274.

Linh BK, Hayashi T, Horii Y. Eimeria vermiformis infection reduces goblet cells by multiplication in the crypt cells of the small intestine of C57BL/6 mice. Parasitol Res 2009; 104(4): 789-794. http://dx.doi.org/10.1007/s00436-008-1256-1. PMid:19005680.

Mai K, Sharman AP, Walker AR, Katrib M, Souza DD, McConville JM, et al. Oocyst wall formation and composition in coccidian parasites. Mem Inst Oswaldo Cruz 2009; 104(2): 281-289. http://dx.doi.org/10.1590/S0074-02762009000200022. PMid:19430654.

McDonnell G, Russell AD. Antiseptics and disinfectants: activity, action, and resistance. Clin Microbiol Rev 1999; 12(1): 147-179. http://dx.doi.org/10.1128/CMR.12.1.147. PMid:9880479.

Mehlhorn H. Encyclopedic reference of parasitology. 4th ed. Berlin: Springer; 2014.

Morton HE. Alcohols. In: Bloch SS, editor. Disinfection, sterilization, and preservation. 3rd ed. Philadelphia: Lea \& Febiger; 1983. p. 225-239.

Mughal TA, Arshad S, Mahboob S. Evaluation of anthelmintic activity of some members of family Moraceae. J Med Plants Res 2013; 7(30): 2275-2279. http://dx.doi.org/10.5897/JMPR2013.4420.

Naderi GA, Asgary S, Sarraf-Zadegan N, Oroojy H, Afshin-Nia F. Antioxidant activity of three extracts of Mores nigra. Phytother Res 2004; 18(5): 365-369. http://dx.doi.org/10.1002/ptr.1400. PMid:15173994.

Nguyen-Pouplin J, Tran H, Tran H, Phan TA, Dolecek C, Farrar J, et al. Antimalarial and cytotoxic activities of ethnopharmacologically selected medicinal plants from South Vietnam.J Ethnopharmacol 2007; 109(3): 417-427. http://dx.doi.org/10.1016/j.jep.2006.08.011. PMid:17010546.

Ody P. The complete guide medicinal herbal. 2nd ed. London: Dorling Kindersley; 2000.

Orengo J, Buendía AJ, Ruiz-Ibáñez MR, Madrid J, Del Río L, Catalá-Gregori P, et al. Evaluating the efficacy of cinnamaldehyde and Echinacea purpurea plant extract in broilers against Eimeria acervulina. Vet Parasitol 2012; 185(2-4): 158-163. http://dx.doi. org/10.1016/j.vetpar.2011.09.024. PMid:21996002.

Pakandl M. Selection of precocious line of the rabbit coccidium Eimeria flavescens Marotel and Guilhon (1941) and characterisation of its endogenous cycle. Parasitol Res 2005; 97(2): 150-155. http://dx.doi.org/10.1007/s00436-005-1411-x. PMid:15986244.

Pan G, Lou CF. Isolation of an 1-aminocyclopropane-1-carboxylate oxidase gene from mulberry (Morus alba L.) and analysis of the function of this gene in plant development and stresses response. J Plant Physiol 2008; 165(11): 1204-1213. http://dx.doi. org/10.1016/j.jplph.2007.02.012. PMid:17997189.

Pérez-Gregorio M, Regueiro J, Alonso-González E, Pastrana-Castro L, Simal-Gándara J. Influence of alcoholic fermentation process on antioxidant activity and phenolic levels from mulberries (Morus nigra L.). Lebensm Wiss Techno/ 2011; 44(8): 1793-1801. http:// dx.doi.org/10.1016/j.Iwt.2011.03.007.

Power EGM. Aldehydes as biocides. Prog Med Chem 1995; 34: 149-201. http://dx.doi.org/10.1016/S0079-6468(08)70107-3. 
Riffat S, Akhtar MS, Javed I, Shah BH. Antinematodal and anticestodal efficacy of Morus alba Linn. stem bark in sheep. PakJ Agric Sci 1986; 23(3-4): 122-129.

Rodrigues EL, Marcelino G, Silva GT, Figueiredo PS, Garcez WS, Corsino J, et al. Nutraceutical and medicinal potential of the Morus species in metabolic dysfunctions. Int J Mo/ Sci 2019; 20(2): 301. http://dx.doi.org/10.3390/ijms20020301. PMid:30646503.

Samaha HA, Haggag YN, Nossair MA, Habib HM. Assessment efficiency of some chemical disinfectants commonly used Against Coccidia in poultry farms. Alex J Vet Sci 2013; 39: 82-90.

Schito ML, Barta JR, Chobotar B. Comparison of four murine Eimeria species in immunocompetent and immunodeficient mice. J Parasitol 1996; 82(2): 255-262. http://dx.doi.org/10.2307/3284157. PMid:8604093.

Sharma SB, Tanwar RS, Rini A, Singh UR, Gupta S, Shukla SK. Protective effect of Morus rubra L. leaf extract on diet-induced atherosclerosis in diabetic rats. Indian J Biochem Biophys 2010; 47(1): 26-31. PMid:21086751.

Shirley MW, Smith AL, Blake DP. Challenges in the successful control of the avian coccidia. Vaccine 2007; 25(30): 5540-5547. http://dx.doi.org/10.1016/j.vaccine.2006.12.030. PMid:17224208.

Stephen B, Rommel M, Daugschies A, Haberkorn A. Studies of resistance to anticoccidials in Eimeria field isolates and pure Eimeria strains. Vet Parasitol 1997; 69(1-2): 19-29. http://dx.doi.org/10.1016/S0304-4017(96)01096-5. PMid:9187026.

Wang L, Gong T, Chen RY. Two new prenylflavonoids from Morus nigra L. Chin Chem Lett 2009; 20(12): 1469-1471. http://dx.doi. org/10.1016/j.cclet.2009.06.035.

Williams RB. A compartmentalised model for the estimation of the cost of coccidiosis to the world's chicken production industry. Int J Parasitol 1999; 29(8): 1209-1229. http://dx.doi.org/10.1016/S0020-7519(99)00086-7. PMid:10576573.

Wunderlich F, Al-Quraishy S, Steinbrenner H, Sies H, Dkhil MA. Towards identifying novel anti-Eimeria agents: trace elements, vitamins, and plant-based natural products. Parasitol Res 2014; 113(10): 3547-3556. http://dx.doi.org/10.1007/s00436-014-41018. PMid:25185667.

Yang $\mathrm{X}$, Yang L, Zheng H. Hypolipidemic and antioxidant effects of mulberry (Morus alba L.) fruit in hyperlipidaemia rats. Food Chem Toxicol 2010; 48(8-9): 2374-2379. http://dx.doi.org/10.1016/j.fct.2010.05.074. PMid:20561945.

Yildirim TT, Ozan G, Dundar S, Bozoglan A, Karaman T, Dildes N, et al. The effects of morus nigra on the alveolar bone loss in experimentally-induced periodontitis. Eur Oral Res 2019; 53(3): 99-105. http://dx.doi.org/10.26650/eor.20190021. PMid:31579889.

Yunus M, Horii Y, Makimura S, Smith AL. Murine goblet cell hypoplasia during Eimeria pragensis infection is ameliorated by clindamycin treatment. J Vet Med Sci 2005; 67(3): 311-315. http://dx.doi.org/10.1292/jvms.67.311. PMid:15805736. 